\title{
Would the Singaporean
}

\section{Approach to Whistleblower Protection Laws Work in Australia?}

\author{
John McLaren ${ }^{1}$, Wesley Kendall ${ }^{2}$ and Laura Rook ${ }^{3}$
}

\begin{abstract}
Federal, State and Territory Governments have enacted a range of statutory laws to protect whistleblowers. The aim of these laws is to provide protection to those individuals in the private and public sector who report unlawful acts made by organizations, contractors and their employees. Provided the disclosure is made in 'good faith', the person making the disclosure is afforded protection from being sued for defamation, breach of confidence under their employment contract or for breach of their common law fiduciary duty. This paper has two purposes; first, the objective of the Australian Government in introducing new whistleblowing laws that extend protection to the consumer protection area and taxation, namely the Treasury Laws Amendment (Whistleblowers) Bill 2017 - Exposure Draft is examined. Secondly, an alternative approach to whistleblowing is considered. By way of contrast, a Singaporean approach which heavily relies on self-reporting and an internal investigation involving an Audit Committee of the corporation is critically examined to assess the potential for introducing a self-reporting approach in Australia. Our analysis finds that in Singapore, culture plays a role in the attitude of the Singaporean employee contemplating reporting unlawful activity and, more importantly in how the disclosure is treated by the corporation or public institution. This paper adds to the literature which examines alternative approaches and attitudes to whistleblowing by providing a comparative discussion of the Australian and Singaporean legal approaches.
\end{abstract}

JEL classification: K22, Z18, M48.

Keywords: Whistleblower laws, Singapore, Australia, Culture, Confucian values.

\footnotetext{
${ }^{1}$ University of Tasmania, Australia.

2 James Cook University, Singapore campus.

${ }^{3}$ University of Wollongong, Australia.
} 


\section{INTRODUCTION}

Federal, State and Territory Governments have enacted a range of statutory laws to protect whistleblowers. Provided the disclosure is made in good faith, the statutory laws, both in the private and public sectors allow an employee or contractor to avoid being sued for defamation, breach of confidence under their employment contract or for breach of their common law fiduciary duty. An alternative approach is offered by the Singapore Government, who has adopted a self-reporting model whereby the unlawful activity of the corporation or public organization is investigated internally.

The Australian Government is in the process of strengthening the whistleblower protection laws in the private sector and introducing new laws to protect whistleblowers in the area of tax. The Government has drafted the Treasury Laws Amendment (Whistleblowers) Bill 2017 - Exposure Draft. It is important to note that while in the process of publishing this article The Treasury Laws Amendment (Enhancing Whistleblower Protections) Bill 2019 (Cth) received Royal Assent on the $12^{\text {th }}$ of March.

The Corporations Act 2001 (Cth) already has provisions designed to protect whistleblowers that disclose breaches of the Act to ASIC. However, these current provisions do not protect whistleblowers that have knowledge of tax avoidance or tax evasion by individual or business taxpayers. The Government envisages that the drafted Treasury Laws Amendment (Whistleblowers) Bill 2017 - Exposure Draft would fill this gap by providing the needed protection to accountants, tax agents, legal advisers, financial service providers, employees of the entity or business contractors that report to the Australian Taxation Office (ATO) breaches of the taxation law. While Singapore does have some policies, which aim to protect whistleblowers, they rely heavily on a self- reporting and management model.

Singapore, which currently is comprised of $74.3 \%$ ethnic Chinese (Department of Statistics Ministry of Trade \& Industry, Republic of Singapore 2017), bears many of the faint echoes of a Confucian-oriented business ethic making it culturally like the Peoples Republic of China. Singapore's earlier economic modernisation has, however, created several significant departures. To ascertain both the foundation and the efficiency of the Singaporean model of good governance and its unique approach to whistleblowing, this paper explores the nature of Singapore's regulatory regimes alongside the cultural context in which these regimes exist.

The paper is structured as follows. Firstly, the current Australian statutory laws and the proposed updated whistleblowing laws are examined. Secondly, the Singaporean approach to protecting whistleblowers is explored. The final part of the paper provides a critical discussion of the merits of both the Singaporean and Australian legal approach to protecting whistleblowers and addresses the question: would the Singapore approach to whistleblower protection laws work in Australia?

\section{WHISTLEBLOWING PROTECTION IN AUSTRALIAN LAW}

The Australian Government is in the process of strengthening the whistleblower protection laws in the private sector and introducing new laws to protect tax whistleblowers. The Government has drafted the Treasury Laws Amendment (Whistleblowers) Bill 2017 Exposure Draft. The Explanatory Memorandum (Treasury Laws Amendment (Whistleblowers) Bill 2017, exposure draft) summarises the current position in Australia states that the objective of the new laws is to provide a stronger framework for the protection of whistleblowers while at the same time attempting to improve corporate compliance and promote an ethical culture. It is also stated that current protections are inadequate or unclear and this is discouraging individuals from disclosing information due to well-founded fears of 
personal and or professional reprisal (Treasury Laws Amendment (Whistleblowers) Bill 2017, Exposure Draft, and Explanatory Materials). In essence the aim of the drafted bill is to amend the current Corporations Act and repeals the existing whistleblower laws including the Taxation Administration Act 1953 so that the gaps in coverage in the corporate and financial sectors are remedied through stronger whistleblower protection that harmonises the law in these sectors with that in the public sector (Whistleblowers Bill 2017, Exposure Draft, Explanatory Materials).

A whistleblower is defined by Australian Securities and Investment Commission (ASIC) (2019) as an insider within an organisation, who reports misconduct or dishonest or illegal activity that has occurred within that same organisation. In academic literature, there are numerous definitions of the act of whistleblowing. However, there are two most commonly referred to. Near and Miceli $(1985, \mathrm{p} 4)$ define whistleblowing as "the disclosure by organisation members (former or current) of illegal, immoral or illegitimate practices under the control of their employers, to persons or organisations that may be able to affect action". Jubb (1999, p 78) on the other hand defines whistleblowing as "... a deliberate nonobligatory act of disclosure, which gets onto public record and is made by a person who has or had privileged access to data or information of an organisation, about non-trivial illegality or other wrongdoing whether actual, suspected or anticipated which implicates and is under the control of that organisation to an external entity having potential to rectify the wrongdoing". Federal, State and Territory Governments all agree that a whistleblower provides a key role in detecting corporate misconduct as government agencies are not always able to detect wrongdoing by corporations or employees in government departments due to their size and commercial secrecy (Australian Treasury 2009). This is supported by numerous literatures including but not limited to research which sees the value of whistleblowers for their contribution in promoting a culture of public accountability and integrity (Chadah 2011) and aligning whistleblowers with prophets who facilitate organisational change through taking a moral stance (Avakian \& Roberts 2011).

There are a range of statutory laws enacted by both the Commonwealth Government and State and Territory Governments that are designed to protect whistleblowers from legal action brought against them by their employer. The statutory laws cover whistleblowers employed or contracted to both private corporations and the public sector such as government departments or government agencies. Whistleblowers are provided with statutory legal protection against their employers in Australia if they are a public servant, an employee or contractor of a corporation (Corporations Act 2001). The reason for the legal protection is that whistleblowers expose themselves to potential legal action because in many instances they breach their fiduciary duty to their employer or a client. The concept of a 'fiduciary duty' is best described by the following passage from the case of Hospital Products Limited v Unites States Surgical Corporation (1984) 156 CLR 41, Mason J made the following observation about the existence of a fiduciary relationship:

The accepted fiduciary relationships are sometimes referred to as relationships of trust and confidence or confidential relations (cf. Phipps v. Boardman [1966] UKHL 2; (1967) 2 AC 46, at p 127), viz., trustee and beneficiary, agent and principal, solicitor and client, employee and employer, director and company, and partners. The critical feature of these relationships is that the fiduciary undertakes or agrees to act for or on behalf of or in the interests of another person in the exercise of a power or discretion which will affect the interests of that other person in a legal or practical sense. The relationship between the parties is therefore one which gives the fiduciary a special opportunity to exercise the power or discretion to the detriment of that other person who is accordingly vulnerable to abuse by the fiduciary of his position. The 
expressions "for", "on behalf of" and "in the interests of" signify that the fiduciary acts in a "representative" character in the exercise of his responsibility, to adopt an expression used by the Court of Appeal.

It is partly because the fiduciary's exercise of the power or discretion can adversely affect the interests of the person to whom the duty is owed and because the latter is at the mercy of the former that the fiduciary comes under a duty to exercise his power or discretion in the interests of the person to whom it is owed. See generally: Weinrib, "The Fiduciary Obligation" (1975) 25 University of Toronto Law Journal 1, at pp.4-8 (Hospital Products Limited v Unites States Surgical Corporation (1984) 156 CLR 41).

The actions of an employee, legal, accounting or financial adviser disclosing information about their employer or client is clearly a breach of their fiduciary duty (For example see Hospital Products Ltd v United States Surgical Corp, (1984) 156 CLR 41, 96 per Mason J). The whistleblower protection law overrides the person's common law fiduciary duty and eliminates any legal action against the discloser for damages. They are also protected against an action for Defamation by an employee or client.

\section{Private Sector Statutory Protection}

The private sector provides protection pursuant to the Corporations Act 2001 (Cth). There are four sections of the Act which are designed to not only protect the whistleblower but also to deter the employer from victimising the whistleblower and if required order the payment of compensation. Appendix A lists the relevant sections of the Corporations Acts 2001 (Cth) that provide whistleblower protection in the private sector. Additionally, private sector legislation to protect whistleblowers is contained in other Acts also listed in Appendix A. These sections can be distilled into the following statements:

- The person who is making the disclosure will only be given protection under the act if they are an officer of the company; an employee of the company; a person who has a contract for the supply of services and goods to the company or an employee of that contractor;

- The disclosure must be made to ASIC; the company's auditor or a member of the audit team, a director, secretary or senior manager of the company or a person authorised to receive the disclosure;

- The discloser must provide their name before making the disclosure;

- The discloser must have reasonable grounds to suspect the information indicates that the company or an officer or employee of the company has contravened the corporation's legislation;

- The discloser must make the disclosure in 'good faith'.

If the above conditions are met the discloser;

- Qualifies for protection from any civil and criminal liability because of making the disclosure

- They are not liable for breaching their employment contract and no rights or remedies can be enforced against them.

- They may be subject to criminal or civil liability if the discloser is found to be involved in the wrongdoing;

- The court can order that a discloser's employment contract can be reinstated. 
If a whistleblower is victimised or is threatened by the employer or company

- The person doing the victimisation action will be prosecuted;

- And if they suffer damage because of the disclosure which resulted in victimisation they may receive compensation.

Whistleblowers employed in the banking sector, the insurance sector or the superannuation industry who had evidence of unlawful activity by a fellow employee could report that conduct to Australian Prudential Regulation Authority (APRA) and receive protection under the law (Banking Act 1959, section 52A; Insurance Act 1973, section 38A).

\section{Public Sector Statutory Protection}

The Commonwealth public sector provides protection for whistleblowers under the Public Interest Disclosure Act 2013 (Cth) (PID Act). Additional public sector legislation to protect whistleblowers is contained in the following:

\section{Fair Work (Registered Organisations) Amendment Act 2016 (Cth)}

For example, a whistleblower employed by a charitable organisation who found evidence of misuse of charitable funds and they reported the unlawful conduct to Fair Work Australia, then the law would provide them with protection (Fair Work Registered Organisations Act 2009, section 337A). In addition to this legislation, the six State and Territory Government provide protection to their own whistleblower within their public sector with similar legislation to the PID Act. These Acts are listed in Appendix A. Essentially, employees within the public sector in the States and Territories are provided with protection if they blow the whistle on unlawful conduct by other employees. This could involve the misappropriation of funds or property or not complying with policy such as adversely favouring other employees. They would report the conduct to the Public Service Board within their State or Territory.

\section{Taxation whistleblowing and the implications of a reward system}

Prior to the proposal of the 'Treasury Laws Amendment (Whistleblowers) Bill 2017 Exposure Draft,' there has been no consideration of protection for whistleblowers in the area of taxation. Currently, The Corporations Act 2001 (Cth) whistleblowers protection provisions do not protect whistleblowers that have knowledge of tax avoidance or tax evasion by individual or business taxpayers. This proposed new law means that the whistleblower is protected by specific provisions in the statutory law against civil actions for breaching their common law fiduciary duty to the client or employer or for defamation. The Government envisages that the law would provide protection to whistleblowers such as accountants, tax agents, legal advisers, financial service providers, employees of the entity or business contractors that report to the Australian Taxation Office (ATO) breaches of the taxation law (The Australian Treasury 2016).

Currently, Australia does not have a reward system for whistleblowers in the public sector or in the private sector pursuant to the Corporations Act. Whistleblowers may receive compensation for loss of employment or persecution, but they are not paid a reward for making the disclosure of illegal activity. The Australian government in its review of whistleblower protection law examines the concept of paying a reward for information from whistleblowers in general and with tax disclosure (Australian Government, The Treasury, above $\mathrm{n} 2,35$.). The UK has a reward system for tax informants but according to the Treasury Review into whistleblowers the HM Revenue \& Customs authority are reluctant to publicise the payments and most of the whistleblowers receive no reward (Australian Treasury 2009 document). 
The Internal Revenue Service in the US pays a reward to tax informers (Riggall 2008). What is now 26 USC 7623(a) has been on the books since March 1867, allowing the Secretary of the Treasury to pay such amounts as he deems necessary 'for detecting and bringing to trial and punishment persons guilty of violating the internal revenue laws or conniving at the same' (Internal Revenue Service, 2018, p 4). The Bush administration introduced the Tax Relief and Health Care Act 2006 which amended the previous informant reward program and introduced a 'whistleblower' program with rewards up to 30 per cent of the tax, penalties and interest collected (Riggall 2008, p 241). As a countervailing measure, US State parliaments have specifically enacted laws making it a crime for accountants and lawyers to disclose confidential information about their clients in relation to taxation matters (Riggall 2008 p 274). Accountants and lawyers in Australia have a similar duty to maintain the privacy and confidentiality of their clients'. Based on 2010 data from the US, since the amendments to the IRS whistleblower program in 2006, the tips to the Inland Revenue Service (IRS) have increased seventy six percent and revenue collected has increased seventy nine percent (Davis-Nozemack, \& Webber 2012, p78). However, whistleblower reward payments have not increased and in fact have decreased forty-four percent (Davis-Nozemack, \& Webber 2012, p79). The whistleblower receives an award of 15 percent but no more than 30 percent of collected proceeds including tax, interest and penalties (Davis-Nozemack, \& Webber 2012, p86). The reason for the decline in reward payments was due to the reward only being paid out of collected proceeds (Davis-Nozemack, \& Webber 2012, p125). If the IRS is unable to collect the tax, then the whistleblower receives nothing. This should be a concern for Australian authorities if they introduce a reward program. Are whistleblowers paid a reward irrespective of tax collected or does the whistleblower wait until the ATO has collected the tax? This may be an important consideration for whistleblowers in some situations if there is no instant reward associated with the disclosure. Another concern for the government is the cost of administering the whistleblower system and subsequent investigations because based on US evidence there was a flood of 'tips' once the Dodd-Frank Act provided for whistleblower rewards (Mavrakis \& Legg 2012).

On the other hand, it is contended that the greatest concern of the US award system is that a reward is paid to a tax professional for breaching their duty of trust and confidence (Morse 2009). Morse (2009) concludes that while enhancing tax collections is important other values deserve consideration such as a tax system that is administered fairly and impartially. He acknowledges that while whistleblowers are important tools to uncover noncompliance thus increasing the perception of fairness, however, a reward system that induces professionals invited into a taxpayer's private sphere in order to breach their confidence detracts from the concept of basic fairness (Morse 2009).

The idea of paying a reward to tax and accounting professionals for breaching their common law fiduciary duty to their client by disclosing activity that may or may not be illegal and in breach of the taxation law, concerns Australians (Creighton 2019). There are situations where tax advisers and accountants are required by law to disclose information about their clients, but there is a substantial body of law and regulations that ensure limited safeguards to taxpayers to protect legal documents covered by legal professional privilege (Taxation Administration Act 1953; Evidence Act 1995). The Commissioner of Taxation may serve a notice on a taxpayer or their tax adviser pursuant to ss 353-310 and 353-315 of the Taxation Administration Act 1953 (Cth) which requires them to provide certain documents or attend to give information personally. In terms of the documents, the tax adviser may be able to claim that legal professional privilege protects the papers from disclosure. The concept of Legal Professional Privilege is contained in the Evidence Act 1995 (Cth), ss 118 and 119. The sections provide for the written communications between a legal 
adviser and their client be kept confidential. Accounting professionals are now required to report illegal activity by their clients under their Code of Conduct, APES 110 (Accounting Professional and Ethics Board 2018). On the other hand, some authors support a reward system for whistleblowing. Brand, Lombard and Fitzpatrick (2013) contend that by offering rewards, more individuals would be encouraged to blow the whistle as it makes it worth their while to come forward and divulge information concerning corporate wrongdoing (Brand, Lombard \& Fitzpatrick 2013). Dr Andrew Leigh, Shadow Assistant Treasurer from the Australian Labor Party also supports this view publishing a policy statement, 'A Fairer Tax System' that confirms that the Australian Labor Party's approach to tax whistleblowing protection is that a reward will be paid equal to 1 percent of any penalty collected by the ATO up to a maximum of $\$ 250,000$ (Leigh 2017).

The question of rewards for whistleblowers will continue to be a contentious issue for taxpayers, tax advisers and governments alike. The position does not appear to be fully resolved in both the UK and the US, and with differing opinions in Australia, any attempt at introducing rewards must be done with full consultation of all relevant stakeholders.

\section{THE SINGAPOREAN APPROACH TO WHISTLEBLOWER PROTECTION}

Singapore has rapidly risen as an Asian economic powerhouse and global financial hub, and it has enjoyed a storied ascent economically and politically for the last 50 years (Jie 2017). By attracting global multinational corporations seeking access to new regional markets and luring corporate relocation by creating a favourable tax and regulatory environment, Singapore has grown exponentially by offering a hospitable destination to direct foreign investment worldwide (Jie 2017). But while embracing the importation of western freemarket policies of trade liberalization, good governance and legal reform, Singapore has not explicitly enacted statutory laws to protect whistleblowers that, according to western wisdom, enhance both public and private accountability by alerting authorities to internal illegality (Teen 2007).Western governments and corporations alike have largely acknowledged that protecting good faith informants from retaliatory employment actions and legal prosecution serves to increase transparency and enforce accountability (Latimer \& Brown 2008). Singapore however, while making the occasional oblique legal suggestion to the efficacy of whistleblowing, has steadfastly declined to mandate its implementation instead primarily preferring to strongly encourage good governance through a rigid system of self-reporting and the rigorous exercise of accounting oversight. The Singapore Government has steadfastly refused to enact specific statutory whistleblowing protection laws unlike Australia and other nations (Cheng 2017).

\section{Singaporean Policies on Good Governance and Whistleblowing}

In the wake of successive financial scandals beginning in the 1990's with companies such as Enron, and rippling up through the 2000's with the Wall Street banking crisis that tore through global financial markets, Western developed countries like the US, UK and Australia have introduced legislation to protect whistleblowers and ostensibly deter corrupt practices and insulate good faith informants from legal repercussions. The US legislation such as the Sarbanes Oxley Act 2002 included civil provisions that protect whistleblowers of publicly traded companies from discrimination and criminal penalties for retaliation against employees who report infractions to law enforcement officials (Company Accounting Reform and Investor Protection Act 2002). In Australia, the Corporations Act 2001 was amended to give officers, employees and contractors who blow the whistle in good faith on their errant employers a qualified privilege against defamation suits, as well as a civil right to seek reinstatement of employment (Corporations Act 2001 Part 94AAA). Singapore however, has 
largely eschewed adopting an externally reactive statutory approach to whistleblower protections, with government citing concerns regarding the creation of incidental costs to business by raising compliance requirements, as well as expanding opportunities for employment and libel litigation that would add an element of risk to operating in the Singaporean market, thus creating a less alluring environment for attracting capital investment (Singaporean Corrupt Practices Investigation Bureau 2017). Instead Singapore has taken a more proactive approach by encouraging vigorous internal systems of accountability, as captured in the Singapore Corporate Governance Code which recommends that 'the AC (Audit Committee) should review arrangements by which the staff of the company may raise concerns about possible improprieties in matters of financial reporting or other matters (Singapore Corporate Governance Code 2018, p14). The AC's objective should be to ensure that arrangements are in place for the independent investigation of such matters and for appropriate follow up action (Singapore Corporate Governance Code 2018). In the following segments, this paper will explore in detail the methods Singapore employs to facilitate and enforce these internal systems of financial accountability and will consider the key factors that have led to this proactive approach, focusing on three different cultural aspects of Singaporean society; ethnic culture, corporate culture and government culture.

\section{Self-Reporting Model}

Singapore has been lauded recently as an Asian pioneer of good corporate governance, and its reputation as a business environment that aggressively enforces financial accountability has earned the city state a reputation as a financial hub which promotes ethical practices and fiscal transparency (Teen 2007). In matters of corporate governance, Singapore has embraced a regulatory regime that emphasizes rigid compliance with self-disclosure requirements, which are legislatively encouraged by pertinent sections of the Criminal Procedures Code (CPC), and enforced by agencies such as the Corrupt Practices Investigation Bureau (CPID) (Tan \& Yen 2011). Singapore's self-reporting regime is premised upon a model that imposes high standards of initial disclosure on key internal accounting personnel and supported by stringent external enforcement of accounting improprieties (Tan \& Yen 2011). The Singapore Stock Exchange (SGX), which operates as both regulator and commercial entity, imposes compliance on its trading members through the Listing Manual (LM), any violations of which constitute a breach of the Singapore Securities and Futures Act, Chapter 289. The LM is aided in its implementation by the Code of Corporate Governance (CCG), a permissive collection of Singaporean industry best practices that directs listed companies to disclose their governance practices in their annual reports (Monetary Authority of Singapore ND). The burden of disclosure and compliance falls to the audit committees, who are required to report to the Board of Directors and external auditors any suspected rules violations (Singapore Corporate Governance Code 2018). The internal investigations which are compelled by the Singaporean regime of self-reporting and full disclosure, are often led and initiated by the audit committee, which is mandated under Section 201(B)(5)(a) of the Singapore Companies Act 2006 to evaluate and report to external auditors the company's internal controls and legal compliance issues. This vigorous system of self-reporting shifts the onus of responsibility to internal auditors and creates a rigid form of enforcement based upon meticulous scrutiny of disclosed financial documents. This rigorous oversight arguably diminishes the need for whistleblowers, under the premise that full disclosure obviates the necessity for external reporting. In the following segment, this paper considers the more specific questions of whistleblower protection within the Singaporean model of self-reporting. 


\section{Whistleblowers}

Although Singaporean statutes have a notable absence of any express employment protections for good faith informants who alert government agencies of corporate malfeasance, there are several statutory provisions that have been judicially interpreted to apply limited protections to whistleblowers. Under the Prevention of Corruption Act 1960 (Cap 241), witnesses who testify in civil or criminal proceedings are not required or permitted to disclose the identity of an informant, granting a certain degree of anonymity to whistleblowers who may fear recrimination if their identity is revealed. Furthermore, The Competition Commission of Singapore (CCS) encourages whistleblowing by not only offering leniency to those who report corrupt practices that they themselves are implicated in, it also offers financial incentives for whistleblowers who report information to the agency (Competition Act, 2004).

Whistleblowing in these circumstances has been weighed by courts in several cases as a mitigating factor that deserves the application of leniency upon the offending whistleblower, provided they contact authorities prior to the commencement of the investigation (For example, PP v Ang Seng Thor, (2011) SGHC 134). Conversely, the courts have rendered punitive sentences for bad faith informants who proffer false information to the authorities. In PP v Mohd Ghalib (2010) SGDC 316, the accused was sentenced to six months imprisonment for providing false statements regarding the conduct of company officers that launched a fruitless and wasteful investigation.

In contrast to the few primary sources of statutory or judicial authority in Singapore concerning whistleblower protections, most guidance is permissively undertaken and encouraged by non-governmental authorities who promote a system of self-regulation through voluntary compliance through the assertive endorsement of codes of good governance. The Guidebook for Audit Committees strenuously recommends all Singaporean companies adopt whistleblowing policies that encourage the internal reporting of accounting irregularities, offer protection to those employees who report to internal officers their concerns of improper conduct, and include assurances of informant confidentiality (Guidebook for Audit Committees 2014). Strong recommendations by nongovernmental organisations to implement internal systems of financial accountability have been widely embraced in Singapore, with recent annual reports showing that $60 \%$ of listed companies in the country have formalised whistleblowing policies in place (Teen 2007). This embrace of an internal model of whistleblowing has had a positive concomitant impact of the perception of whistleblowing itself, with the prospect of internal resolution remaining preferable to external reporting. In a survey of Certified Public Accountants Australia members in Singapore, Hong Kong and Malaysia conducted in part by the Corporate Governance and Financial Reporting Centre (CGFRC) at the National University of Singapore, found that $59 \%$ of respondents claiming that they would report financial misconduct without a whistleblowing policy in place, but with a policy of protection for good faith informants the percentage of respondents who would report increases by another $36 \%$ (Teen 2007, p9). The cultural factors that have been instrumental in effecting the uniquely Singaporean paradigm of good governance through diligent self-reporting are explored in the following segment.

\section{Whistleblower Culture in Singapore}

Culture is generally thought of as the foundation of the social order and systems we live in and the rules we abide by (Schein 2010). Organisational culture includes the structure of organisations within which we work such as government, non-profit, public and private, as well as the micro and sub units within these organisations such as occupational groups and microsystems internal and external to the organisation itself (Schein 2010). Since organisational culture is made up of both macro and micro systems and sub groups, it is 
argued that culture can and is influencing both individual and collective work practices. Singaporean attitudes toward reporting company misconduct are a product of a confluence of factors. According to Teen $(2007, \mathrm{p} 7)$, there is 'an attitude amongst some that whistleblowing is an act of disloyalty, especially if the complaint is made to an external source, such as a regulatory authority'. The operant sentiment underlying this prevailing notion of disloyalty is firmly rooted in the Confucian concept of the importance of the collective predominating over the expression of individual will, and absent obeisance to one's superiors the company cannot function effectively (Kennan 2007). Essentially, collectivist cultures belong to and emphasise the group, protect the interests of the group, generally avoid conflict and tend to not express their thoughts openly (Dwyer 2016). What this means is that "Potential whistleblowers that are embedded deeply within Asian cultural virtues, the teachings of Confucius and collectivism dimension may discourage whistleblowing behaviour within organisations" (Ahmad 2011, p30).

According to Shen (2014), Confucianism is a set of ideological beliefs based upon the '6 Classic' texts of its founder, the Chinese philosopher Confucius in 551BC. Confucianism blended religious, historical, cultural and political premises seamlessly into one unified philosophical tradition which extolled the virtues of social harmony, and the value of communal devotion to the maintenance of a moral society (Tan 2012). During the Asian economic boom of the 1960s, historical conceptions of Confucianism were recast as the philosophical foundation of the Newly Industrialized Economies (NIE's) of Taiwan, South Korea, Singapore and Hong Kong (Chong 2002: Tan 2012). With Japan serving as an economic anchor, other Asian countries sought to frame the nascent emerging trend of Asian economic modernity as a counter to western conceptions of market control; a friendlier version of Asian authoritarianism that in its previous incarnations would have been perceived as incompatible with western free market models (Pang \& De Myer 2015). Focusing on Asian cultural traits such as high rates of personal savings, deference to authority, strong work ethic and the inclination to placing societal good above individual gain, the Confucian ethic was promoted not only as the driving force behind Asian economic growth, but as a justification for enforcing rigid domestic constraints (Chan 1996). As a result, Confucian ethics and Asian capitalism became inextricably bound in the minds of both foreign observers as well as Asians themselves. In this context, the act of whistleblowing in Asia, and in Singapore in particular, is viewed as antithetical to Confucian ethical practices. Indeed, as the public statement from one Singaporean company embroiled in an accounting scandal which refused to adopt even an internal whistleblowing policy succinctly attests, "The board considers that it is undesirable to implement a formal whistle blower policy as such a policy will serve to weaken the spirit de corps amongst the staff' (Teen 2007, p7).

The belief that providing an opportunity to employees to engage in ostensible acts of disloyalty against the company harms the employees themselves may seem a self-serving declaration to those inhabiting Western countries, but in Confucian societies like Singapore and China the public disclosure of embarrassing facts that implicate an employee's company in financial scandal will ultimately result in all employees 'losing face', a high social cost for the company as a collective (Kaplan 2015). According to Keenan (2007), Confucianism imposes interdependency between company and employee in which the social context of behaviour is the dominant frame, rendering individual actions against the collective interests of the company socially unacceptable. This Confucian view contrasts sharply with Western conceptions of the autonomous individual, in isolation and motivated primarily by internal attributes, and less beholden to the collective needs of the company (Shun \& Wong 2004). This individual disinclination act outside the scope of social constraints, leads inevitably to the creation of an organizational propensity in Confucian-oriented societies like Singapore to 
denounce whistleblowing as an act of betrayal to the communal society to which one belongs (Cheung 2014).

In an Asian ethnic cultural context, this organisational propensity serves as a powerful deterrent to exerting individual action against a superior and is grounded in a philosophical ideology that has permeated into both economic and government attitudes toward whistleblowers (Graham \& Milind 2017; Wild 2013). Confucian societies, although regionally diverse, share a collectivistic culture that emphasizes shared views, norms and a focus on maintaining social relationships, and tend to view individual actions that undermine collective cohesion as existential threats to the community (Keenan 2007). The Confucian tradition of elevating the welfare of society above the interests of the individual, as opposed to the Western tradition of individuals acting outside group interests has formed an obstacle to the adoption of Western-styled whistleblower protections as antithetical to the Confucian concepts of preservation of the collective (Zheng 2015). And although pressure from transnational organisations Singapore to reform good corporate governance laws to be better aligned with the Anglo-Saxon model of good corporate governance, Singapore has sought a middle position by adopting its proactive self-reporting model, which allows it to eschew the putative betrayal of external complaints while enforcing rigid internal accountability (Aguilera \& Cuervo-Cazurra 2009; Duh 2017).

In summary, Singapore has adopted a proactive system of corporate financial accountability that bridges the ideological chasm between the Western conceptions of good governance through aggressive reactive regimes of regulatory enforcement and the Eastern Confucian paradigm of maintaining company cohesion and collective social relationships through vigorous internal controls and transparency in audit disclosures. As these different systems are predicated upon the interrelated ethnic, economic and government cultures that define Singaporean society, the ability to transfer the largely successful implementation of self-reporting systems of good governance that diminish the role of the external whistleblower may not be easily adopted in Western societies. The same Western notions of individualism that permit the autonomy of the whistleblower to disregard the constraints of the community and pursue a course of action that requires betraying company loyalties, may be the same independence of thought that allows the rogue executive to cast off societal constraints and commit acts of corporate misconduct (Tsahuridu \& Vandekerckhove 2008). However, it can be said in closing that the productive collaboration among divergent cultural approaches to good corporate governance promotes further understanding and is beneficial to crafting more effective systems of internal and external systems of accountability.

\section{WOULD THE SINGAPORE APPROACH WORK IN AUSTRALIA?}

There are two main issues to consider when examining the most appropriate approach to encouraging whistleblowing. First, do stronger whistleblower protection laws lead to a greater level of reporting of unlawful activity and second, do cultural factors such as that associated with a Confucian ideology produce a better outcome for both the whistleblower and the corporation?

It is arguable that with all of the statutory law that currently exists in Australia and the new law proposed to be introduced with the Treasury Laws Amendment (Whistleblowers) Bill 2017 more whistleblowers will report unlawful activity to external bodies such ASIC and the Australian Tax Office (ATO). For example, when Jeff Morris from the Commonwealth Bank blew the whistle on unlawful activity taking place in the wealth management section of the bank, there were other employees that were also aware of the wrongdoing. However, he was the only employee to report the activity to ASIC (Eyers 2014). Many other employees in 
that part of the Commonwealth Bank had knowledge of the unlawful activities that were taking place but chose to remain silent. Jeff Morris paid a high price for blowing the whistle as he has been subject to death threats, received no assistance from ASIC, lost his job and as a result, his health has suffered (Barker 2017). Ferguson (2016) states that had there been stronger protection laws, more employees would have come forward.

The Royal Commission into the Misconduct in the Banking, Superannuation and Financial Services Industry provides an exemplar of the potential one whistleblower can have on the system. Established on 14 December 2017, The Commissioner, the Honourable Kenneth Madison Hayne AC QC, was authorised by the Australian Government to oversee the investigation into misconduct. While the Commission cannot resolve individual disputes nor can it fix or award compensation or make orders requiring a party to a dispute to take or not to take any action, the Royal Commission will likely impact all entities by bringing new light to what are 'community expectations', culture and governance (Atkins \& Charleton, 2019; Winter 2019). Thus, it is arguable that one change that may come of the findings of the Royal Commission is the examination of whistleblower protections as one way of monitoring the health of an organisations culture (Casson 2019). This and an examination of the implications of the Royal Commission have yet to be realized. Thus further research is recommended.

From the above analysis of the Singaporean system of handling whistleblowers and its approach to self-reporting is vastly different from the Australian approach. In Singapore, the current method of dealing with whistleblowing is that of keeping the complaint in-house and giving the responsibility of investigating the report to the Audit Committee. The whistleblower is not victimized by the employer after making the report, and corporate harmony is maintained. In the above example of Jeff Morris and the Commonwealth Bank, if Australia had adopted the Singaporean approach to whistleblowing, then he may not have been victimized. Furthermore, embracing a Singaporean culture within organizations would mean changing our individualistic cultural approach to a more collectivist cultural approach. This would mean placing the needs of society before the needs of oneself (Tavakoli et al. 2003). In the case of Jeff Morris, it is arguable that this may have resulted in more people coming forward, forgoing their individual concerns of reprisal. It became apparent through the Royal Commission that it was not just one instance of misconduct with many of Australia's top banks being implicated in unlawful wrongdoings (Karp 2016). The culture within Australian banks has been described as an aggressive sales drive culture which emphasizes profit at all costs (Chau \& Clark 2018). The question all Australians should be asking themselves is why do we not focus on Australian society cultural values when it comes to the managing of and development of good governance frameworks within Australian organisations?

Adopting a collective approach and development of an ethical culture within Australian organisations would mean that there would be less reliance on statutory laws to protect whistleblowers. Singapore has adopted a proactive system of corporate financial accountability that bridges the ideological chasm between the Western conceptions of good governance through aggressive, reactive regimes of regulatory enforcement and the Eastern Confucian paradigm of maintaining company cohesion and collective social relationships through vigorous internal controls and transparency in audit disclosures. As these different systems are predicated upon the interrelated ethnic, economic and government cultures that define Singaporean society, the ability to transfer the largely successful implementation of self-reporting systems of good governance that diminish the role of the external whistleblower may not be easily adopted in Western societies, especially Australia. However, in light of recent events in the banking industry, perhaps Australia should be considering a more proactive cultural approach to whistleblowing. The question is why have Australian 
corporations not considered alternative ways of ensuring good corporate governance? With the recent Royal Commission finding that the responsibility for the misconduct rested with boards and senior management, time may provide us with the solution, once the wider implications for the management and governance of corporate Australia have been delineated and further researched (Lumsden 2019).

\section{CONCLUSION}

This paper examined the current and proposed whistleblower protection laws in Australia, and by way of contrast reviewed Singapore's approach to whistleblowing. It was found that the Australian Government believes that the current provisions for the protection of whistleblowers in Australia are inadequate. Thus, the proposed Treasury Laws Amendment (Whistleblowers) Bill 2017 - Exposure Draft aims to fill the gap in current legislation by providing an extended stronger framework for the protection of whistleblowers including the financial and taxation professions, with the intention that the bill will also improve corporate compliance and promote an ethical culture.

Singapore's approach to whistleblowing was examined, and it was found that their approach to whistleblowing is largely influenced by Confucian cultural principles. This means that the principles of collectivism are embedded within a framework of self-reporting and governance within an organization rather than relying solely on frameworks to support external disclosure. What the analysis of the Singaporean approach tells us is that both culture and the law can work together to provide good governance in organizations. This would appear to be a complex process, yet none the less, one that we believe would provide added protection for employees turned whistleblowers, as it ultimately deters corruption and wrongdoing within organizations through strong cultural values.

In conclusion, to answer the question posed: would the Singapore approach to whistleblower protection laws work in Australia? No. It would be difficult for a Confucian culture to be introduced into the predominantly individualistic culture of Australia. However, we do believe that for effective whistleblower protection, a cultural approach that might consider Singapore's commitment to communal devotion in the maintenance of a moral society would do more benefit than harm. It is important to note that while in the process of publishing this article The Treasury Laws Amendment (Enhancing Whistleblower Protections) Bill 2019 (Cth) received Royal Assent on the $12^{\text {th }}$ of March. This bill provides a single, strengthened whistleblower protection regime covering the corporate and financial sectors. Coming into effect no later than January 1, 2020, this Act will impact all public and large propriety companies, and no doubt have a greater impact on an individual's decision to blow the whistle.

\section{REFERENCES}

Accounting Professional and Ethics Board (2018) Issued Standards, Viewed $3^{\text {rd }}$ February 2019, https://www.apesb.org.au/page.php?id=12

Aguilera, R.V. and Cuervo-Cazurra, A., (2009) 'Codes of good governance' Corporate Governance: an International Review, 17(3), pp.376-387. https://doi.org/10.1111/j.1467-8683.2009.00737.x

Ahmad, S. A. (2011). Internal Auditor and Internal Whistleblowing Intentions : A Study of Organisational, Individual, Situational and Demographic Factors, Viewed $2^{\text {nd }}$ January 2019, https://ro.ecu.edu.au/theses/152 
Australian Securities Investment Commission (2019) Whistleblowing, Viewed $1^{\text {st }}$ April 2019, https://asic.gov.au/about-asic/asic-investigations-and-enforcement/whistleblowing/

Australian Treasury (2009) Improving Protections for Corporate Whistleblowers, Options Paper, Viewed $26^{\text {th }} \quad$ April http://archive.treasury.gov.au/contentitem.asp?ContentID $=1620$

Atkins, S., Charlton, P. (2019) Chartered Secretary: The Banking Royal Commission Final Report: Culture and Governance Implications [online]. Governance Directions, Vol. 71, No. 2, 65-70. Viewed $25^{\text {th }}$ January 2019 https://search.informit.com.au/documentSummary; $\mathrm{dn}=239588449254522 ;$ res=IELAP A > ISSN: 2203-4749

Avakian, S., Roberts, J., (2012) 'Whistleblowers in Organisations: Prophets at Work?', Journal of Business Ethics, 110(1), pp.71-84. https://doi.org/10.1007/s10551-011-1148-7

Banking Act 1959, Section 52A, Disclosures Qualifying for Whistleblower Protection. http://www.austlii.edu.au/cgibin/viewdoc/au/legis/cth/consol act/ba195972/s52a.html

Barker, A, (2017) 'Banking Royal Commission: Speaking out against CBA had 'horrific impact' on Whistleblower,' Viewed $1^{\text {st }}$ May 2019 https://www.abc.net.au/news/201711-30/banking-whistleblower-jeff-morris-tells-of-horrific-impact/9212536

Brand, V., Lombard, S., and Fitzpatrick, J. (2013) 'Bounty Hunters, Whistleblowers and a New Regulatory Paradigm', Australian Business Law Review, Vol 4

Casson, J. (2019) 'What are we Learning from Royal Commissions and Inquiries?' Governance Directions, Vol. 71, No. 2: 97-102.

Chadah, S., (2011) 'Containing Corruption: Role of Whistleblowers,' Indian Journal of Public Administration, 57(3), pp.741-757. https://doi.org/10.1177/0019556120110333

Chan, A., (1996) 'Confucianism and Development in East Asia,'Journal of contemporary Asia, 26(1), pp.28-45. https://doi.org/10.1080/00472339680000031

Chau, D., Clark, E. (2018) Banking Royal Commission: How did we get here? ABC News, Viewed $26^{\text {th }}$ April 2019 https://www.abc.net.au/news/2017-11-30/banking-royalcommission-how-did-we-get-here/9210248

Cheng, W. (2017) 'Responding to Anonymous Whistleblowers', The Business Times Singapore Nov. 13, 2017, Viewed $21^{\text {st }}$ December 2018 https://www.businesstimes.com.sg/companies-markets/boardroommatters/responding-to-anonymous-whistleblowers

Cheung, H. (2014) 'No Indians No PRCs': Singapore's Rental Discrimination Problem. BBC News Online. Viewed $4^{\text {th }}$ May 2019 http://www.bbc.com/news/world-asia-26832115

Chong, T., 2002. Asian values and Confucian ethics: Malay Singaporeans' dilemma. Journal of Contemporary Asia, 32(3), pp.394-406.

https://doi.org/10.1080/00472330280000271

Company Accounting Reform and Investor Protection Act 2002, 116 Stat 745, Available at https://www.govinfo.gov/content/pkg/PLAW-107publ204/pdf/PLAW107publ204.pdf

Competition Act 2004, Sec. 66. Viewed $13^{\text {th }}$ November 2018 https://sso.agc.gov.sg/Act/CA2004

Corporations Act 2001 Part 94AAA, Viewed $3^{\text {rd }}$ March 2019, http://www5.austlii.edu.au/au/legis/cth/consol_act/ca2001172/

Creighton, A. (2019) 'Rewards Bring Out the Dibber Dobbers, The Australian Newspaper, Viewed $7^{\text {th }}$ October 2019 https//www.theaustralian.com.au/opinion/columnists/rewards-bring-out-the-dibberdobbers/news-story/876edd9a1703b838252c71fd935b1fae 
Davis-Nozemack, K., Webber, S., (2012) 'Paying the IRS Whistleblower: A Critical Analysis of Collected Proceeds,' Virginia Tax Review, 32, p.77.

https://doi.org/10.2139/ssrn.1967699

Department of Statistics, Ministry of Trade \& Industry, Republic of Singapore (2017) Population Trends, Viewed $26^{\text {th }}$ April 2019 https://www.singstat.gov.sg//media/files/publications/population/population2017.pdf

Duh, M., (2017) 'Corporate Governance Codes and Their Role in Improving Corporate Governance Practice,' In Corporate Governance and Strategic Decision Making. IntechOpen. https://doi.org/10.5772/intechopen.69707

Dwyer, J., 2016. Communication for Business and the Professions: Strategies and Skills. Pearson Higher Education Australia.

Eyers, J. (2014) 'The Man Who Blew the Whistle on CBA', The Australian Financial Review, Viewed 25 ${ }^{\text {th }}$ April 2019 http://financialresolutions.com.au/in-the-news/theman-who-blew-the-whistle-on-cba/

Evidence Act 1995, Sections 118 and 119, Viewed $4^{\text {th }}$ May 2019 http://www.austlii.edu.au/cgibin/viewdoc/au/legis/cth/consol act/ea199580/s118.html

Fair Work (Registered Organisations) Amendment Act 2016, Viewed $17^{\text {th }}$ March 2019 https://www.legislation.gov.au/Details/C2016A00079

Fair Work (Registered Organisations) Amendment Act 2009, Viewed 17 ${ }^{\text {th }}$ March 2019 https://www.legislation.gov.au/Details/C2017C00147

Ferguson, A. (2016) Whistleblowers Need More Protection, Speech to the Press Freedom Australia Dinner, The Walkleys foundation. Viewed $25^{\text {th }}$ June 2016, http://www.walkleys.com/whistleblowers-need-more-protection-adele-fergusonspeech-at-the-press-freedom-australia-dinner-2016/

Guidebook for Audit Committees 2014, Section 2.2.52. Viewed 26 ${ }^{\text {th }}$ April 2018 http://www.mas.gov.sg/ /media/MAS/Regulations\%20and\%20Financial\%20Stability /Regulatory $\% 20$ and $\% 20$ Supervisory $\% 20$ Framework/Corporate $\% 20$ Governance $\% 20 \mathrm{o}$ f\%20Listed $\% 20$ Companies/Guidebook\%20for $\% 20$ ACs $\% 202$ nd $\% 20$ edition.pdf

Graham, P. J., Milind, S. (2017) 'Does National Culture Impact Capital Budgeting Systems?', Australasian Accounting, Business and Finance Journal, 11(2), 43-60. doi:10.14453/aabfj.v11i2.4

Hospital Products Limited v Unites States Surgical Corporation (1984) 156 CLR 41. Viewed $14^{\text {th }}$ June 2018 https://lawcasesummaries.com/knowledge-base/hospital-products-ltdv-united-states-surgical-corporation-ltd-1984-156-clr-42/

Insurance Act 1973, Section 38A Disclosures Qualifying for Whistleblower Protection, Viewed $4^{\text {th }}$ May 2019 http://www.austlii.edu.au/cgibin/viewdoc/au/legis/cth/consol_act/ia1973116/s38a.html

Internal Revenue Service (2018) History of the Whilstleblower/Informant Program, Viewed $26^{\text {th }} \quad$ April 2019 https://www.irs.gov/compliance/history-of-the-whilstleblowerinformant-program

Jie, W. (2017) 'Singapore's Transformation into a Global Financial Hub', The National University of Singapore, School of Public Policy.

Jubb, P.B., (1999) 'Whistleblowing: A Restrictive Definition and Interpretation,' Journal of Business Ethics, 21(1), pp.77-94. https://doi.org/10.1023/A:1005922701763

Kaplan, R., (2015) 'Asia's Rise is Rooted in Confucian Values', Wall Street Journal, Viewed $5^{\text {th }}$ June 2018 https://www.wsj.com/articles/asias-rise-is-rooted-in-confucian-values$\underline{1423254759}$ 
Karp, P. (2016) Timeline: Banking Scandals in Australia since 2009, The Guardian, Viewed $26^{\text {th }}$ March 2019 https://www.theguardian.com/australia-news/nginteractive/2016/apr/29/timeline-banking-scandals-in-australia-since-2009

Keenan, J. (2007) 'Comparing Chinese and American Managers on Whistleblowing', Employee Response Rights Journal 19, 85-94. https://doi.org/10.1007/s10672-0079036-0

Shun, K. Wong, D. (2004) Confucian Ethics, A Comparative Study of Self, Autonomy and Community, Cambridge, Cambridge University Press. https://doi.org/10.1017/CBO9780511606960

Latimer, P., Brown, A. J. (2008) 'Whistleblower Laws: International Best Practice' UNSW Law Journal, 31(3), 766-794. https://doi.org/10.2139/ssrn.1326766

Leigh, A. (2017) A Fairer Tax System for Millions, Not Millionaires- media Release, Viewed $26^{\text {th }}$ April 2019

www.andrewleigh.com/a fairer_tax_system_for_millions_not_millionaires

Life Insurance Act 1995, Viewed $6^{\text {th }}$ January 2019 https://www.legislation.gov.au/Details/C2018C00074

Lumsden, A., 2019. The Wider Implications of the Hayne Report for Corporate Australia. Available at SSRN 3342855. https://doi.org/10.2139/ssrn.3342855

Mavrakis, N. and Legg, M (2012) 'The Dodd-Frank Act Whistleblower Reforms Put Bounty on Corporate Non-Compliance: Ramifications and Lessons for Australia', 40 Australian Business Law Review 26, 34.

Morse, E. (2009) 'Whistleblowers and Tax Enforcement: Using Inside Information to Close the "Tax Gap"” Akron Tax Journal 1, 36.

Monetary Authority of Singapore (ND) Singapore Code of Corporate Governance, Viewed $8^{\text {th }}$ February 2018 http://www.mas.gov.sg/regulations-and-financialstability/regulatory-and-supervisory-framework/corporate-governance/corporategovernance-of-listed-companies/code-of-corporate-governance.aspx

Near, J.P. Miceli, M.P., (1985) Organizational Dissidence: The Case of Whistle-Blowing. Journal of Business Ethics, 4(1), pp.1-16. https://doi.org/10.1007/BF00382668

Pang, E. F., De Meyer, A. (2015) 'Within \& Without: Singapore in the World; the World in Singapore. 1-300. Research Collection Lee Kong Chian School Of Business

Phipps v. Boardman [1966] UKHL 2; (1967) 2 AC 46 https://swarb.co.uk/phipps-vboardman-hl-1966-2/

Prevention of Corruption Act 1960, Chapter 241, Part VI, Sec. 36. Viewed $26^{\text {th }}$ April 2019 https://sso.agc.gov.sg/Act/PCA1960

Protected Disclosure Act 2012, Victoria. Viewed $7^{\text {th }}$ January 2019 https://www.parliament.vic.gov.au/publications/protected-disclosure-act-2012

PP v Ang Seng Thor (2011) SGHC 134. Accessed 26.04.19 at : https://www.supremecourt.gov.sg/docs/default-source/moduledocument/judgement/ma-9214-of-2016-heng-tze-yong-V-pp-(post-type-6)-(14-sept)pdf.pdf

PP v Mohd Ghalib (2010) SGDC 316. Accessed 26.04.19 at: https://www.supremecourt.gov.sg/docs/default-source/module-document/judgement/2016-sghc-134-(ma)-muhammad-zuhairie-adely-v-pp-pdf.pdf

Public Interest Disclosure Act 2013, Viewed $16^{\text {th }}$ December 2018 https://www.legislation.gov.au/Details/C2013A00133

Public Interest Disclosures Act 1994, New South Wales. Viewed $7^{\text {th }}$ January 2019 http://www5.austlii.edu.au/au/legis/nsw/consol_act/pida1994313/ 
Public Interest Disclosure Act 2012, Australian Capital Territory. Viewed $8^{\text {th }}$ January 2019 https://www.bing.com/search?q=Public+Interest+Disclosure+Act+2012,+Australian+ Capital+Territory\&src $=$ IE-SearchBox\&FORM=IESR4S

Public Interest Disclosures Act 2002, Tasmania. Viewed $10^{\text {th }}$ January 2019 https://www.legislation.tas.gov.au/view/html/inforce/current/act-2002-016

Public Interest Disclosure Act 2003, Western Australia. Viewed $11^{\text {th }}$ January 2019 https://www.legislation.wa.gov.au/legislation/statutes.nsf/main_mrtitle_767_homepag e.html

Public Interest Disclosure Act 2008, Northern Territory. Viewed $12^{\text {th }}$ January 2019 https://legislation.nt.gov.au/en/Subordinate-Legislation/Public-Interest-DisclosureRegulations

Riggall, K., (2008) 'Should Tax Informants Be Paid-The Law and Economics of a Government Monopsony,' Virginia Tax Review, 28, p.237.

Royal Commission into Misconduct in the Banking, Superannuation and Financial Services Industry (2017) Viewed $5^{\text {th }}$ February 2018 https://financialservices.royalcommission.gov.au/Pages/default.aspx

Schein, E.H., (2010) 'Organizational Culture and Leadership' (Vol. 2). John Wiley \& Sons. Schein, E.H., (2010) 'Organizational Culture and Leadership' (Vol. 2). John Wiley \& Sons.

Shen, V. (2014) 'Dao Companion to Classical Confucian Philosophy', Springer Science and Business Media. https://doi.org/10.1007/978-90-481-2936-2

Singapore Corporate Governance Code (2018), Guideline 12.7.Viewed $26^{\text {th }}$ April 2019 http://www.mas.gov.sg/Regulations-and-Financial-Stability/Regulatory-andSupervisory-Framework/Corporate-Governance/Corporate-Governance-of-ListedCompanies/Code-of-Corporate-Governance.aspx

Singapore Securities and Futures Act 2001, Chapter 289, Sec. 33. Viewed 26 ${ }^{\text {th }}$ April 2019 https://sso.agc.gov.sg/Act/SFA2001

Singapore Companies Act 2006 Part V, Div. 1. Accessed 26.04.19 at https://sso.agc.gov.sg/Act/CoA1967?ProvIds=P1III-

Singaporean Corrupt Practices Investigation Bureau (2017) 'Whistle-blowers Protected Under Law,' Forum Letter Reply. Viewed 18th March 2019 at https://www.cpib.gov.sg/press-room/press-releases/forum-letter-reply-whistleblowers-protected-under-law

Superannuation Industry (Supervision) Act 1993, Viewed $6^{\text {th }}$ January 2019 https://www.legislation.gov.au/Details/C2017C00052

Tan, C. (2012) 'Our Shared Values' in Singapore: A Confucian Perspective,'Educational Theory, 62(4), 449-463. https://doi.org/10.1111/j.1741-5446.2012.00456.x

Tan, J., Yen, S. K (2011) Chapter 11: Singapore, Bourtin, N. (eds) The Internal Investigations Review, Gideon Roberton, pg. 115- 134

Tavakoli, A.A., Keenan, J.P. Cranjak-Karanovic, B., (2003) 'Culture and Whistleblowing an Empirical Study of Croatian and United States Managers Utilizing Hofstede's Cultural Dimensions,' Journal of Business Ethics, 43(1-2), pp.49-64. https://doi.org/10.1023/A:1022959131133

Taxation Administration Act 1953 Sections 353-10 and 353-15. Viewed $4^{\text {th }}$ May 2019 http://www.austlii.edu.au/cgibin/viewdoc/au/legis/cth/consol act/taa1953269/sch1.html

The Australian Treasury 2016, Viewed $20^{\text {th }}$ April 2019 https://treasury.gov.au/consultation/review-of-tax-and-corporate-whistleblowerprotections-in-australia

Teen, Y. M. (2007) 'Whistleblowing: Recent Developments and Implementation Issues', Private Sector Opinion, Issue 5, A Global Corporate Governance Publication, Viewed 
$26^{\text {th }}$ April 2019

https://www.ifc.org/wps/wcm/connect/d145190048a7e693a757e76060ad5911/GCGF \%2BPSO \%2Bissue\%2B5\%2Bscreen.pdf?MOD=AJPERES

Treasury Laws Amendment (Enhancing Whistleblower Protections) Act (2019), Viewed $4^{\text {th }}$ May 2019 https://www.legislation.gov.au/Details/C2019A00010

Treasury Laws Amendment (Whistleblowers) Bill (2017), exposure draft, Explanatory Materials 8. https://consult.treasury.gov.au/market-and-competition-policydivision/whistleblowers-bill-2017/supporting documents/Exposure\%20Draft.pdf

Tsahuridu, E., Vandekerckhove, W. (2008) 'Organisational Whistleblowing Policies: Making Employees Responsible or Liable?’ Journal of Business Ethics, 82(1), 107-118. https://doi.org/10.1007/s10551-007-9565-3

Weinrib, E (1975) 'The Fiduciary Obligation' 25 University of Toronto Law Journal 1, at pp.4-8 https://doi.org/10.2307/824874

Whistleblowers Protection Act 1993, South Australia. Viewed $6^{\text {th }}$ January 2019 https://www.legislation.sa.gov.au/LZ/C/A/WHISTLEBLOWERS\%20PROTECTION $\% 20 \mathrm{ACT} \% 201993 . \mathrm{aspx}$

Whistleblowers Protection Act 1994, Queensland. Viewed $6^{\text {th }}$ January 2019 https://www.legislation.qld.gov.au/view/pdf/asmade/act-1994-068

Wild, S. (2013) Accounting for Heritage, Cultural and Community Assets - Alternative Metrics from a New Zealand Māori Educational Institution, Australasian Accounting, Business and Finance Journal, 7(1), 2013, 3-22. doi:10.14453/aabfj.v7i1.2

Winter, J. (2019) 'Financial services Royal Commission - impacts on our profession?' Australian Restructuring Insolvency \& Turnaround Association Journal, Vol. 31, No. $10-11$. Viewed $4^{\text {th }} \quad$ May 2019 https://search.informit.com.au/documentSummary; $\mathrm{dn}=289953370565437 ;$;res=IELAP A>ISSN: 2206-317X. [cited 30 Apr 19].

Zheng, M. (2015) 'Different Business Ethics in Chinese and Western Cultures' Dissertation submitted as partial requirement for the conferral of M.Sc. in Business Administration 


\section{$\underline{\text { Appendix A }}$}

Private Sector Protection:

Corporations Act 2001 (Cth)

The four relevant sections that provide protection are as follows:

(i) Section 1317AA, Disclosures qualifying for protection under this Part

(ii) Section 1317AB - Disclosure that qualifies for protection not actionable etc.

(iii) Section 1317AC - Victimisation prohibited - Actually causing detriment to another person

(iv) Section 1317AD - Right to compensation

Additional private sector legislation to protect whistleblowers is contained in the following:

- Banking Act 1959 (Cth)

- Insurance Act 1973 (Cth)

- Life Insurance Act 1995 (Cth)

- Superannuation Industry (Supervision) Act 1993 (Cth)

Public Sector Protection:

The six State and two Territory Governments provide protection to their own whistleblowers within their public sector with similar legislation to the PID Act. The legislation is contained in the following statutes:

- Whistleblowers Protection Act 1993, South Australia

- Whistleblowers Protection Act 1994, Queensland

- Public Interest Disclosures Act 1994, New South Wales

- Public Interest Disclosure Act 2012, Australian Capital Territory

- $\quad$ Protected Disclosure Act 2012, Victoria

- Public Interest Disclosures Act 2002, Tasmania

- Public Interest Disclosure Act 2003, Western Australia

- Public Interest Disclosure Act 2008, Northern Territory 